\title{
Ti Foil Supported Three-Dimensional Porous Silver Film as a High Performance Catalyst for Hydrazine Electrooxidation in KOH Solution
}

\author{
Ran Liu ${ }^{1, *}$, Jinling Yin ${ }^{2}$, Dianxue Cao ${ }^{2}$ \\ ${ }^{1}$ Department of Chemistry, School of Food Engineering, Harbin University, Harbin, 150086, \\ P.R.China \\ ${ }^{2}$ Key Laboratory of Superlight Materials and Surface Technology of Ministry of Education, College of \\ Materials Science and Chemical Engineering, Harbin Engineering University, Harbin, 150001, \\ P.R.China \\ *E-mail: liuran7907@ 163.com
}

doi: $10.20964 / 2017.12 .45$

Received: 17 May 2017 / Accepted: 30 September 2017 / Published: 12 November 2017

\begin{abstract}
An efficient electrocatalyst for hydrazine electrooxidation is beneficial for elevating the cell performance of direct hydrazine fuel cells (DHFCs). Electrocatalysts with a highly porous structure have been extensively studied in the field of electrochemistry, owing to their large catalytically active area and favorable mass transfer. Therefore, in this thesis, a one-step galvanostatic electrodeposition method related to the hydrogen evolution reaction is adopted to deposit a porous silver film on Ti foil $(\mathrm{Ag} / \mathrm{Ti})$. Electrochemical measurements are introduced to estimate the ability of the resultant $\mathrm{Ag} / \mathrm{Ti}$ electrode to catalyze hydrazine electrooxidation. $\mathrm{Ag} / \mathrm{Ti}$ displays an evident peak at approximately -0.2 $\mathrm{V}$ due to hydrazine electrooxidation. The correspondent peak current density reaches $7.7 \mathrm{~mA} \mathrm{~cm}^{-2}$ in $0.02 \mathrm{M} \mathrm{N}_{2} \mathrm{H}_{4} \cdot \mathrm{H}_{2} \mathrm{O}$ and $1.0 \mathrm{M} \mathrm{KOH}$. This good electrocatalytic capacity may have a bearing on the micropore structure, which offers facile access of the electrolyte to the Ag/Ti surfaces and enables gases to diffuse away from the electrode surfaces promptly to vacate the activated sites.
\end{abstract}

Keywords: Silver; Porous film; Electrodeposition; Hydrazine electrooxidation

\section{$\underline{\text { FULL TEXT }}$}

(C) 2017 The Authors. Published by ESG (www.electrochemsci.org). This article is an open access article distributed under the terms and conditions of the Creative Commons Attribution license (http://creativecommons.org/licenses/by/4.0/). 